\title{
Tobacco farming: overcoming an understated impediment to comprehensive tobacco control
}

\author{
Raphael Lencucha (1) ,' Jeffrey Drope 10 , ${ }^{2}$ Peter Magati, ${ }^{3}$ \\ Gumilang Aryo Sahadewo (1) ${ }^{4}$
}

${ }^{1}$ School of Physical and Occupational Therapy, McGill University, Montreal, Quebec, Canada

${ }^{2}$ University of Illinois at Chicago, Chicago, Illinois, USA

${ }^{3}$ Consultant, World Health Organization, Nairobi, Kenya ${ }^{4}$ Economics, Universitas Gadjah Mada, Sleman, DIY, Indonesia

\section{Correspondence to}

Dr Raphael Lencucha, McGill University, Montreal, Canada; raphael.lencucha@mcgill.ca

Received 28 May 2021 Accepted 3 December 2021
Check for updates

(c) Author(s) (or their employer(s)) 2022. No commercial re-use. See rights and permissions. Published by BMJ.

To cite: Lencucha R, Drope J, Magati P, et al. Tob Control 2022;31:308-312.

\section{ABSTRACT}

Tobacco farming has emerged as an important concern for tobacco control advocates. Tobacco-growing countries face unique and important challenges to comprehensive, intersectoral tobacco control. These challenges stem from narratives that position tobacco as an important driver of economic growth and development, perpetuated by tobacco interests with close ties to government decision-making. While the global tobacco control movement has enshrined a commitment to alternatives to tobacco growing, there remain numerous obstacles. Tobacco growing is often situated in contexts with limited markets for other agricultural products, limited knowledge and economic resources to pursue alternatives, and/or a structure that favours industry control over the supply chain, all constraining the decision space of farmers. An evidenceinformed approach is necessary to address tobacco supply, including growing, processing, manufacturing and trade, in this complex context. This paper reviews the economic, environmental and policy context of tobacco growing with an emphasis on the past decade of empirical work on the political economy of tobacco supply and introduces strategies to pursue alternatives. This analysis debunks many of the arguments used to perpetuate the narrative of tobacco's prosperity and provides critical insights into the institutional constraints faced by government sectors in pursuing a policy of alternatives.

\section{INTRODUCTION: OVERVIEW OF TOBACCO GROWING WORLDWIDE}

Tobacco growing received important recognition in the Framework Convention on Tobacco Control (FCTC) through the inclusion of articles (17 and 18). Importantly, Article 17 of the FCTC highlights the need to support economically viable alternatives to tobacco growing. Many countries have taken measures to reduce tobacco growing including financial inducements to move away from tobacco growing, elimination of subsidies for tobacco-based enterprises and investment in alternative economic opportunities for farmers. ${ }^{1}$ Yet tobacco growing continues to sit in the margins of tobacco control efforts. In part, this marginal attention stems from the rationale that supply is an outcome of demand and demand reduction will naturally result in supply reduction. Although there is some truth to this perspective, scholarship is beginning to illustrate important linkages between the political economy of tobacco growing, namely the institutions, ideas and interests that are mobilised to shape public policy and market practices, ${ }^{2}$ and the ability of governments to implement comprehensive tobacco control measures. ${ }^{3}$ One indication of this relationship is that the largest tobacco-producing countries are often those who experience the greatest internal (ie, domestic tobacco control policy) and external (eg, to the FCTC) resistance to tobacco control efforts. This association between leaf production and limited advancement in tobacco control measures is attributed to the power of tobacco interests, and the embeddedness of these interests in government institutions, which affords influence over tobacco policy. ${ }^{4}$ These interests amplify the message of tobacco's importance to economies and farming households, serving as a powerful counterforce to tobacco control efforts.

In this context, tobacco is touted as an indispensable economic commodity, an economic boon to governments and a major source of employment. ${ }^{5-7}$ However, the numbers tell a different story. In almost all cases, the contribution of tobacco to overall GDP is minimal (see table 1). From a list of the top 13 gross producers of unmanufactured leaf, the share of tobacco to GDP does not exceed $2.9 \%$ (see table 1). Tobacco's contribution to total exports is mostly minimal (less than $3 \%$ for $10 / 13$ countries) except for Tanzania (6.3\%), Zimbabwe $(13.8 \%)$ and Malawi, the most tobacco-dependent economy at almost $60 \%$ (see table 1 ). Even the amount of agricultural land dedicated to tobacco at its highest is 3\% and 2\% in China and Malawi, respectively, and is less than $0.5 \%$ in the other major tobacco-growing countries.

The number of farmers growing tobacco is also often overexaggerated by tobacco interests. If we use the International Tobacco Growers Association figures, which are likely inflated, and compare those with total employment in the agricultural and associated sectors (eg, fisheries), we see no higher than $2 \%$. The benefits to households that grow tobacco are also limited, and recent studies have illustrated the detrimental economic impact of tobacco growing on most households (see table 1). For example, studies in five major tobacco-producing countries find that after adjusting for labour and other costs, the most farming households made is roughly US\$324/year in the most profitable year in Indonesia with massive losses in countries like Zambia (see figure 1). Even the more profitable farming households typically fall well below the World Bank international poverty line of US\$1.90/ day. Yet the narrative of prosperity persists.

While the narrative of prosperity benefits from the scarcity of economic evaluation of tobacco farmer livelihoods, the evidence base illustrating 
Table 1 Country-level data of tobacco production for the top tobacco-producing countries in the world*

\begin{tabular}{|c|c|c|c|c|c|c|c|}
\hline Country & $\begin{array}{l}\text { The share of } \\
\text { tobacco farming } \\
\text { to GDP in } 2018 \\
(\%)\end{array}$ & $\begin{array}{l}\text { Numbers of } \\
\text { tobacco farmers } \\
\text { by country }\end{array}$ & $\begin{array}{l}\text { Share of tobacco } \\
\text { farmers to total } \\
\text { employment in } \\
\text { agriculture sector (\%) }\end{array}$ & $\begin{array}{l}\text { Share of tobacco } \\
\text { farmers to overall } \\
\text { employment }(\%)\end{array}$ & $\begin{array}{l}\text { Share of tobacco exports } \\
\text { to total commodity } \\
\text { export in } 2018(\%)\end{array}$ & $\begin{array}{l}\text { Share of tobacco } \\
\text { exports to overall } \\
\text { exports in } 2018 \\
(\%)\end{array}$ & $\begin{array}{l}\text { Share of agricultural } \\
\text { land for tobacco } \\
\text { farming in } 2014(\%)\end{array}$ \\
\hline China & 0.067480 & $5497000(2017)$ & 1.9262394 & 0.7127087 & 0.0564555 & 0.0539464 & 3.57 \\
\hline India & 0.037924 & 348806 (2020) & 0.1353900 & 0.0744266 & 0.3136025 & 0.3078659 & 0.24 \\
\hline Brazil & 0.073748 & $160200(2020)$ & 0.7302897 & 0.1692893 & 0.8351883 & 0.8214403 & 0.15 \\
\hline Zimbabwe & 2.881452 & $122323(2020)$ & 2.4862904 & 1.8300320 & 15.3586822 & 13.8091314 & 0.49 \\
\hline USA & 0.005314 & $6150(2020)$ & 0.0378173 & 0.0038069 & 0.1077477 & 0.1157419 & 0.04 \\
\hline Indonesia & 0.025456 & $527688(2017)$ & 1.0117532 & 0.4248894 & 0.4017758 & 0.4022222 & 0.37 \\
\hline Zambia & 1.250362 & $17637(2020)$ & 0.3775204 & 0.2709508 & 2.0192082 & 1.5741121 & 0.28 \\
\hline Bangladesh & 0.030106 & $100000(2017)$ & 0.3119531 & 0.1550109 & 0.3457389 & 0.2576211 & 0.55 \\
\hline Tanzania & 0.006931 & 60005 (2018) & 0.3016069 & 0.2327625 & 9.6420765 & 6.2570922 & 0.22 \\
\hline Argentina & 0.041801 & 21389 (2019) & 0.6571323 & 0.1140339 & 0.6106504 & 0.6136438 & 0.04 \\
\hline Kenya & 0.023098 & $36000(2019)$ & 0.2112974 & 0.1557356 & 2.5454545 & 2.3123123 & 0.04 \\
\hline Malawi & 0.201952 & $50816(2020)$ & 1.0161168 & 0.6692127 & 69.3137976 & 58.9067308 & 2.14 \\
\hline Mozambique & 0.399495 & $137042(2017)$ & 1.5167903 & 1.1456254 & 5.2399423 & 3.1689756 & 0.15 \\
\hline
\end{tabular}

* Data sources: tobacco raw production value data from Food and Agriculture Organization (http://www.fao.org/faostat/en/\#data/QV2). Tobacco farmer data from the database of various sources (eg, COMESA) at the International Tobacco Growers Association (an active opponent to tobacco control with direct ties with industry) (https://atlas.tobaccoleaf.org/) and tobacco farmer data for Kenya from Tobacco Tactics (https://tobaccotactics.org). Sectoral employment data for elementary occupations and skilled agricultural, fishery and forestry workers and overall country level employment data from International Labour Organization (https://www.ilo.org/shinyapps/bulkexplorer35/?lang=en\&segment=indicator\&id=EMP_2EMP_SEX_OCU_NB_A4). Export data of commodities from Total Trend Economy (https://trendeconomy.com/data/commodity_h2/TOTAL) and Bangladesh commodity export data from Bangladesh Bank (https://www.bb.org.bd/econdata/ export/exp_rcpt_comodity.php). Tobacco export data and total export data from The Observatory of Economic Complexity (https://oec.world/en) that uses source data from CEPII French Economic Research Center and country-level data. ${ }^{6}$ The share of agriculture land from Tobacco Atlas (6th edition) (https://tobaccoatlas.org/).

the social, environmental and health harms of tobacco growing is extensive. Deforestation, child labour and a multitude of health hazards have been associated with tobacco growing across countries and regions. ${ }^{8}$ The crude disregard of these problems in efforts to promote tobacco as an economic commodity demonstrates how embedded the narrative of prosperity has become in policy spheres. With the increase in evidence of the precariousness of tobacco growing as a viable and sustainable economic commodity, we are seeing shifts away from tobacco by farmers and in the development plans of many tobacco-growing countries. ${ }^{910}$ While the crop itself is a major problem for growers and tobacco control proponents, the ability to shift to other crops or economic activities is hindered by numerous factors. We present these factors later in this discussion. Our aim here is to review the economic, environmental and policy context of tobacco growing with an emphasis on the past decade of empirical work on the political economy of tobacco supply and introduce strategies for governments and tobacco control actors to support alternatives.

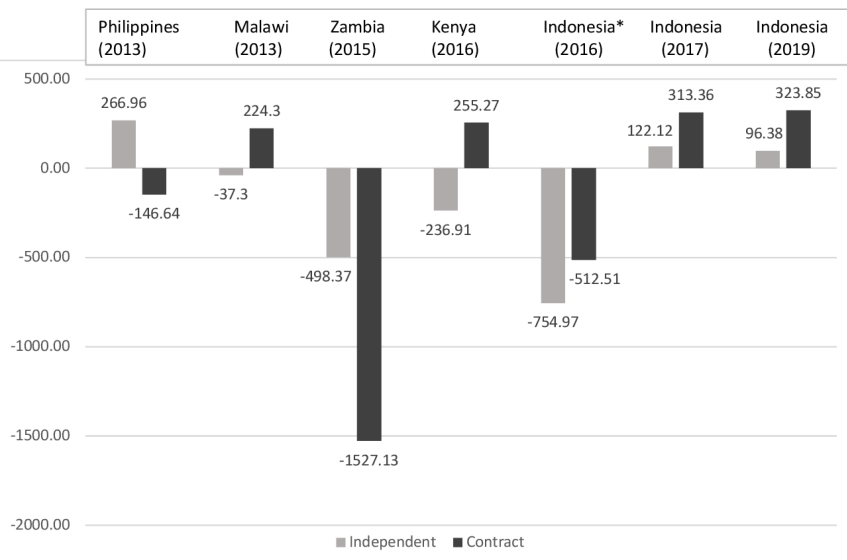

Figure 1 Average profits and losses for individual tobacco farming households in USD. *Indonesia data include tobacco and non-tobacco farming profits.

\section{WHY DO GOVERNMENTS SUPPORT TOBACCO? INSTITUTIONAL LEGACIES AND ECONOMIC NARRATIVES}

Widespread tobacco consumption started to take hold in the early 1800 s and tobacco continued to gain prominence as a lucrative commodity into the mid-1900s. Large-scale commercial production followed this trajectory. The 'globalisation' of tobacco growing was mobilised by the European powers in many of the colonies. For example, the British empire sought to supplant its reliance on the USA for tobacco by commandeering and allocating large swaths of fertile land in sub-Saharan Africa for tobacco growing. ${ }^{11}$ It was in the late 1800 s when support for tobacco growing began to be institutionalised and systematised in many of these countries. ${ }^{6}{ }^{11}$ Scholars have illustrated how these institutional legacies perpetuate support for tobacco growing to this day. For example, in Malawi, the prominence of tobacco has been maintained by formal and informal arrangements between companies and government agencies that keep leaf prices low and ensure maximum benefits to tobacco companies. ${ }^{6}$ These institutional arrangements, including longstanding tobacco governing boards with tobacco industry representation, and agricultural research agencies with mandates to improve the quality and quantity of tobacco being produced, serve to perpetuate both material support for tobacco growing and a normative environment that unquestioningly views tobacco as an important economic commodity. ${ }^{57}$

While the institutional entrenchment of tobacco is longstanding, there has been a recent expansion of production, especially a massive increase in small holder farming, in lowand middle-income countries (LMICs), with a reduction in high-income countries (HICs). ${ }^{12}$ The shift to LMICs is mainly driven by companies seeking lower production costs, with many countries welcoming these new investments. In Africa alone, more than 20 countries grow tobacco on a commercial scale, with most government officials believing that increased tobacco growing is essential for their economic success. ${ }^{713}$ With agriculture contributing a significant percentage of GDP in many LMICs, cash crops continue to be seen as key drivers of development and employment. 


\section{WHY ARE FARMERS ATTRACTED TO TOBACCO?}

Studies in tobacco-growing countries suggest that a robust supply chain is one of the main reasons why farmers grow tobacco, along with the perceived economic viability and access to markets. ${ }^{14-16}$ However, evidence actually suggests that tobacco farmers have a relatively weak bargaining position in the supply chain. Across tobacco-growing countries, the tobacco supply chain comprises a limited number of buyers-for example, tobacco industry warehouses or middlemen-and relatively large numbers of farmers acting as price takers. ${ }^{17}$

Another dynamic in the tobacco supply chain is the increasing use of contract farming. A high proportion of tobacco farmers in tobacco-growing LMICs engage in contract farming with tobacco leaf companies. This dynamic means that government is further removed from tobacco farmers leaving total control of the supply chain to industry. For example, in Kenya, governments do not invest resources towards research on tobacco farming, leaving information on tobacco growing to the industry, who usually provide information that suits their narrative. ${ }^{16} 17$ The contract arrangements allow farmers to take essential inputs such as seeds, fertilisers and pesticides on loan to be paid back on selling their leaf to the lender. ${ }^{18-20}$ Studies find that contract tobacco farmers pay higher prices for inputs. ${ }^{21}$ Because of poor access to affordable transportation, tobacco farmers who live far from economic centres are more likely to engage in contract farming to ensure transportation of their leaf to the market. ${ }^{22}$ From the perspective of tobacco companies, contract farming induces farms to produce higher quality leaf while maximising the companies' profitability. The evidence demonstrates that profitability dominates the dynamic and is typically comes at the expense of farmers through the companies' near total control of the supply chain. ${ }^{12212324}$

Contract tobacco farmers must sell their leaf to these leafbuying companies. These companies set the grade and price for the leaf, consistently resulting in low prices of tobacco leaf and unfair grading. ${ }^{161720}$ Tobacco farmers must accept the unfavourable grade and price to avoid the risk of rejection by leaf buyers since they legally have little recourse to sell elsewhere. Unsurprisingly, evidence across countries shows that contract farmers are consistently dissatisfied with the price. Contract farming also induces a cycle of debt among many farmers as they are obligated to pay off their losses by contracting in the subsequent season with the same contracting leaf buyer, an arrangement that is challenging for farmers to exit. ${ }^{25}$ In the end, contract farming is designed perniciously with the buyer as the beneficiary at the direct expense of the sellers.

\section{BURDEN ON TOBACCO-GROWING HOUSEHOLDS}

Tobacco is also costly to grow for households. Studies consistently show proportionally higher costs of agricultural inputs for tobacco crops compared with non-tobacco crops grown in the same geographical areas in the same season. ${ }^{192627}$ In addition to physical inputs, because tobacco farming is more labour intensive than most crops, tobacco farmers spend more on hired labour costs for tobacco crops than for non-tobacco crops. ${ }^{17}$ This situation frequently leads farmers to underestimate the cost of labour and inputs. The result is that farmers overestimate their profits, which partially explains why they think tobacco is lucrative.

Tobacco farmers also tend to overestimate their profits because they fail to account for costs of household labour. Households' labour poses significant opportunity costs because household labour could have undertaken on-farm and/or off-farm economic endeavours that would bring income to households. ${ }^{242628}$ In the case of Indonesia, Kenya and Zambia, household labour costs were higher than hired labour costs for both tobacco and nontobacco farming. Household labour costs were also significantly higher for tobacco farming than non-tobacco farming. A recent study in Malawi, Kenya and Zambia finds that knowledge likely matters: more educated farmers are more able to estimate labour costs and therefore determine that tobacco farming is not lucrative, ${ }^{16}$ which suggests an intervention point for governments wishing to improve farmers' livelihoods.

Tobacco farming is also destabilising due to the income fluctuations from year to year. One of the main explanations of good and bad years is rainfall shocks as tobacco farming relies on drier weather conditions particularly near harvest period. ${ }^{17}{ }^{29}$ More importantly, evidence consistently shows that non-tobacco crops provide better and more stable income, in both good and bad farming years. ${ }^{24}$

Finally, the environmental and social impacts of tobacco production are often not considered in the economic calculus of governments or farmers. The environmental impacts stem from degradation of soil quality, heavy use of agricultural chemicals (eg, herbicides, pesticides and inorganic fertilisers), water pollution and deforestation. ${ }^{181930}$ Over 11.4 million metric tonnes of wood are required annually for tobacco curing. This results in deforestation, thereby contributing to increased $\mathrm{CO}_{2}$ emissions, climate change, loss of biodiversity, and desertification or land degradation. Generally, tobacco is grown as a monocrop, leaving the tobacco crop and soil vulnerable to many diseases and pests. ${ }^{30}$ To control for pests and diseases, farmers apply large quantities of chemicals that are harmful to the environment and their own health. ${ }^{31}$ In many cases, farmers apply these chemicals and harvest leaf without protective equipment, exposing them to respiratory and skin diseases, including green tobacco sickness, a form of acute nicotine poisoning. ${ }^{32} 33$ These problems are compounded by the pervasive use of child labour and heightened vulnerability of children to these harms, in addition to the educational and social consequences of this practice. ${ }^{34}$ Recent evidence from Argentina points to consistently poorer self-reported health outcomes and smoking rates among youth involved in tobacco farming. ${ }^{35}$ Researchers in Brazil have extensively documented the poor health and social outcomes of tobacco farmers ranging from chronic low back pain to chronic endebtedness to tobacco companies. ${ }^{3637}$

\section{WHAT DOES TOBACCO PRODUCTION MEAN FOR TOBACCO CONTROL?}

For most tobacco control proponents in tobacco-growing countries, there is clear evidence that economic arguments hinder their efforts. Key institutional mandates at politically powerful ministries such as trade, finance, agriculture and labour are frequently at cross-purposes, undermining tobacco control. For example, in late 2020, defending meagre excise tax increases on cigarettes, a prominent finance minister from Asia cited tobacco farming as a key reason to temper the increase. ${ }^{38}$ These institutions frequently support tobacco production actively while dismissing or resisting tobacco control, ostensibly for economic reasons. The mandates that partly drive their behaviours need to be understood to advance tobacco control in tobacco-growing countries. ${ }^{39}$ In this final section, we outline these mandates. The facts of tobacco's precarious economic benefits can be targeted and framed within these mandates to strengthen the tobacco control message.

\section{Engaging with sectoral mandates}

For trade ministries, there is frequent emphasis on export maximisation. ${ }^{40}$ Although global demand for tobacco leaf 
has diminished in recent years, ${ }^{12}$ demand for inexpensive leaf remains sufficiently robust and a 'race-to-the-bottom' among low-cost producers has developed. ${ }^{41}$ Trade ministries are rarely evaluated beyond exports' values. Most farmers sell their leaf at low prices and often at a loss, while multinational leaf buyers sell the same leaf at much higher prices reaping most or even all the reward. These export earnings are thus accruing to mostly foreign entities, yet the volume of export serves the stated ministerial mandate.

For finance ministries, balance of payments (BOP) and tax revenues are key macro-fiscal considerations. Whereas tobacco exports sometimes generate desirable foreign exchange, which is favourable for BOP, labour-intensive leaf cultivation rarely attracts significant foreign direct investment and there is poor consideration of imported goods related to tobacco production, which both work against the BOP. In many cases, the value of the imports required to grow tobacco (eg, inorganic fertiliser, pesticide, herbicide, etc) is significant, thereby hurting $\mathrm{BOP}^{42}$ Similarly, most tobacco-growing countries are net importers of higher-value manufactured tobacco products (eg, cigarettes), and the value of these imports typically dwarfs that of the raw tobacco exports. Many finance officials also perceive that tobacco generates sizeable tax revenues. This may be somewhat accurate for manufactured tobacco products—although it tragically overlooks the vast economic, health and social damage that tobacco use causes-but the evidence suggests that most governments tax tobacco leaf lightly, if at all. ${ }^{43}$

For agriculture and labour ministries, the principal mandates are typically overall production and job creation, respectively, but too often at the expense of high-quality livelihoods for households. Where rural economic opportunities are limited and ministries' budgets small, it is easy to succumb to the enormous pressures to increase output and jobs by accepting tobacco industry support to farmers even though economic outcomes are mostly feeble.

\section{Narratives, information and market dynamics}

Even entities that should be or are well informed on tobacco's harms invoke economic arguments when defending tobacco production. Health ministries often believe or purport to believe that tobacco remains an important economic commodity, acknowledging this as a barrier to their tobacco control work. ${ }^{744}$ This belief in tobacco's economic importance likely results from a power asymmetry within government wherein health must negotiate skilfully within the narratives and mandates of other ministries to make policy, given their often weaker position. ${ }^{45}$ At the same time, health ministries likely operate with similar information deficits as other ministries about the true cost of tobacco production. Along with evidence on the long-term negative economic effects of tobacco, health ministries need to be given strong tools to demonstrate that tobacco production is a poor bargain overall and undermines public health.

The continued success of the tobacco prosperity narrative is driven considerably by weak information and the strong voice of tobacco interests. These interests continue to endear themselves to publics and governments through systematic corporate social responsibility initiatives and tireless lobbying efforts. ${ }^{13} 46$ The continued influence of tobacco interests highlights the importance of coupling alternative livelihood initiatives with strategies to prevent industry influence in policy spaces. ${ }^{4}$ Until recently, rigorous data and analysis about tobacco farming livelihoods were scarce. However, as we demonstrate here, there is new compelling economic research across multiple countries about farmers' poor-quality livelihoods ${ }^{17} 2123$ and compelling evidence on viable alternatives, and it is incumbent on tobacco control communities to help governments understand and use it to counter these mostly false economic narratives. In the rare country where tobacco farmers do fare relatively well, it will likely take a different type of evidence to move towards alternatives. Such considerations can include issues of sustainability and broader issues of healthy product supply chains.

There is a parallel dynamic at the household level. Like governments who use poor or partial information to make economic decisions, farmers typically enter contracts to grow leaf with little or no knowledge of the price they will receive, the grade that will be assigned to their tobacco, the costs of inputs and how much of their crop they will be able to sell. The information deficit is amplified by industry's ability to control information flow and decision-making along the supply chain.

Evidence-based interventions driven by governments to improve farmers' livelihoods can address these deficits and be low cost. Farmers consistently identify the barrier of weak domestic marketplaces for non-tobacco crops and cite tobacco companies favourably as 'ready buyers' even if the prices are poor. ${ }^{14} 1547$ Engendering more dynamic marketplaces connecting sellers to buyers of other products would make tobacco production less attractive. Similarly, improving farmers' access to market information across crops and other products would help them to choose crops in demand and find buyers that offer higher prices. ${ }^{22}$ Because farmers complain consistently about non-tobacco crops' low prices, ${ }^{16}$ improving value chains would incentivise farmers to shift away from tobacco because even lightly processed goods fetch significantly higher market prices than raw ones. ${ }^{48}$ Farmers consistently and positively cite tobacco companies' financing including upfront inputs and cash loans, which governments could offer justly and accessibly in non-tobacco contexts. Many micro-finance schemes demonstrate positive income effects on borrowers and the high levels of repayment suggest they can be low cost for the lenders. Misplaced structural reform programmes reduced agricultural extension services, ${ }^{49}$ but evidence demonstrates that rural poverty decreases, and consumption increases when quality services and supports are present. ${ }^{50}$ Although more expensive, well-targeted programmes to improve infrastructure such as better roads, artesian wells, and irrigation could lift entire communities. ${ }^{51}$

\section{CONCLUSION}

Tobacco control proponents must demand that governments be more ambitious and stop perpetuating a prosperity narrative for tobacco farming that evidence mostly contradicts and that undermines public health. While true that tobacco farming is happening in many economically challenging places, research consistently shows these regions are far from bereft of other economic possibilities. Imagination and investment will help engender prosperous and just alternatives.

Twitter Peter Magati @magatipeter and Gumilang Aryo Sahadewo @gasahadewo Acknowledgements The authors would like to thank Shashika Bandara for his research assistance.

Contributors RL coordinated the drafting of the manuscript. All authors contributed to the manuscript outline, wrote portions of the first draft, reviewed and contributed to subsequent drafts, and agreed to the final version of the manuscript.

Funding This study was funded by Canadian Institutes of Health Research (Grant number: PJT166086), National Institute on Drug Abuse (Grant number: R01DA035158) and National Cancer Institute (Grant number: R01TW010898).

Competing interests None declared. 
Patient consent for publication Not applicable.

Ethics approval This study does not involve human participants.

Provenance and peer review Commissioned; externally peer reviewed.

ORCID iDs

Raphael Lencucha http://orcid.org/0000-0002-9273-2027

Jeffrey Drope http://orcid.org/0000-0003-0147-9722

Gumilang Aryo Sahadewo http://orcid.org/0000-0002-0543-054X

\section{REFERENCES}

1 Lee T. Country practices in the implementation of Article 17 (Economically sustainable alternatives to tobacco growing) of the WHO Framework Convention on Tobacco Control. Geneva: Framework Convention Secretariat, 2019.

2 Milner HV. Interests, institutions, and information: domestic politics and international relations. Princeton University Press, 1997: 326

3 Lencucha R, Drope J. How does tobacco growing impact advancement in demand reduction measures? Tob Prev Cessat 2021;7:1-4.

4 Fooks GJ, Smith J, Lee K, et al. Controlling corporate influence in health policy making? An assessment of the implementation of Article 5.3 of the World Health Organization Framework Convention on Tobacco Control. Global Health 2017;13:12.

5 Smith J, Fang J. 'If you kill tobacco, you kill Malawi': structural barriers to tobacco diversification for sustainable development. Sustainable Development 2020;28:1575-83.

6 Smith J, Lee K. From colonization to globalization: a history of state capture by the tobacco industry in Malawi. Rev Afr Polit Econ 2018;45:186-202.

7 Lencucha R, Reddy SK, Labonte R, et al. Global tobacco control and economic norms: an analysis of normative commitments in Kenya, Malawi and Zambia. Health Policy Plan 2018:33:420-8.

8 Lecours $\mathrm{N}$. The harsh realities of tobacco farming: a review of socioeconomic, health and environmental impacts. In: Tobacco control and tobacco farming: separating myth from reality. Ottawa, ON: Anthem Press (IDRC), 2014

9 Lencucha R, Moyo T, Labonte R, et al. Shifting from tobacco growing to alternatives in Malawi? A qualitative analysis of policy and perspectives. Health Policy Plan 2020:35:810-8.

10 Sahadewo GA, Drope J, Li Q, et al. In-and-out of tobacco farming: shifting behavior of tobacco farmers in Indonesia. Int J Environ Res Public Health 2020;17:9416.

11 Rubert SC. A most promising weed: a history of tobacco farming and labor in colonial Zimbabwe, 1890-1945. Ohio: Ohio University Press, 1998.

12 Drope J, Schluger N, Cahn Z. Tobacco atlas. 6th ed. Atlanta, GA: American Cancer Society and Vital Strategies, 2018. https://tobaccoatlas.org/

13 Otañez MG, Mamudu HM, Glantz SA. Tobacco companies' use of developing countries' economic reliance on tobacco to lobby against global tobacco control: the case of Malawi. Am J Public Health 2009;99:1759-71.

14 Appau A, Drope J, Witoelar F, et al. Why do farmers grow tobacco? A qualitative exploration of farmers perspectives in Indonesia and Philippines. Int J Environ Res Public Health 2019;16:2330.

15 Talukder A, Haq I, Ali M, et al. Factors associated with cultivation of tobacco in Bangladesh: a multilevel modelling approach. Int J Environ Res Public Health 2020;17:4277

16 Appau A, Drope J, Goma F, et al. Explaining why farmers grow tobacco: evidence from Malawi, Kenya, and Zambia. Nicotine Tob Res 2020;22:2238-45.

17 Sahadewo GA, Drope J, Li Q, et al. Tobacco or not tobacco: predicting farming households' income in Indonesia. Tob Control 2021;30:320-7.

18 Hu T-wei, Lee AH. Tobacco control and tobacco farming in African countries. J Public Health Policy 2015:36:41-51.

19 Hussain AG, Rouf ASS, Shimul SN, et al. The economic cost of tobacco farming in Bangladesh. Int J Environ Res Public Health 2020;17:9447.

20 Nguenha N, Cunguara B, Bialous S, et al. An overview of the policy and market landscape of tobacco production and control in Mozambique. Int J Environ Res Public Health 2021;18:343.

21 Magati $\mathrm{P}$, Lencucha $\mathrm{R}$, Li Q, et al. Costs, contracts and the narrative of prosperity: an economic analysis of smallholder tobacco farming livelihoods in Kenya. Tob Control 2019;28:268-73.

22 Li Q, Magati P, Lencucha R, et al. The economic geography of Kenyan tobacco farmers livelihood decisions. Nicotine Tob Res 2019;21:1711-4

23 Makoka D, Drope J, Appau A, et al. Costs, revenues and profits: an economic analysis of smallholder tobacco farmer livelihoods in Malawi. Tob Control 2017;26:634-40.

24 Sahadewo GA, Drope J, Witoelar F. The economics of tobacco farming in Indonesia: results from two waves of a farm-level survey. Chicago, IL: University of Illinois at Chicago, 2020.
25 Chingosho R, Dare C, van Walbeek C. Tobacco farming and current debt status among smallholder farmers in Manicaland Province in Zimbabwe. Tob Control 2021;30:610-5.

26 Goma F, Drope J, Zulu R. Economics of tobacco farming in Zambia. Lusaka, Zambia: University of Zambia School of Medicine; American Cancer Society, 2015.

27 Drope J, Li Q, Araujo E. The economics of tobacco farming in Indonesia. Washington, D.C.: World Bank Group, 2017

28 Magati $\mathrm{P}, \mathrm{Li}$ Q, Drope J. The economics of tobacco farming in Kenya. Nairobi, Kenya: Institute of Legislative Affairs; American Cancer Society, 2016.

29 Syahid Muttaqin A, Suarma U, Nurjani E, et al. The impact of climate variability on tobacco productivity over Temanggung Regency, Indonesia. E3S Web Conf. 2019;76:04003.

30 Lecours N, Almeida GEG, Abdallah JM, et al. Environmental health impacts of tobacco farming: a review of the literature. Tob Control 2012;21:191-6.

31 Arcury TA, Quandt SA. Health and social impacts of tobacco production. J Agromedicine 2006;11:71-81.

32 Bartholomay P, Iser BPM, de Oliveira PPV, et al. Epidemiologic investigation of an occupational illness of tobacco harvesters in southern Brazil, a worldwide leader in tobacco production. Occup Environ Med 2012:69:514-8.

33 Park S-J, Lim H-S, Lee K, et al. Green tobacco sickness among tobacco Harvesters in a Korean village. Saf Health Work 2018;9:71-4.

34 Davies R. BAT and Imperial tobacco firms profited from child labour, law firm alleges. The Guardian [Internet], 2020. Available: https://www.theguardian.com/business/ 2020/dec/18/bat-imperial-tobacco-firms-child-labour-law-firm-alleges [Accessed 8 Oct 2021].

35 Alderete E, Livaudais-Toman J, Kaplan C, et al. Youth working in tobacco farming: effects on smoking behavior and association with health status. BMC Public Health 2020;20:84.

36 Portes LH, Machado CV, Turci SRB, et al. Tobacco control policies in Brazil: a 30-year assessment. Cien Saude Colet 2018;23:1837-48.

37 dos ReisMM, de OliveiraAPN, Turci SRB, et al. Knowledge, attitudes, and practices of women farmers concerning tobacco agriculture in a municipality in southern Brazil. Cad Saúde Pública [Internet] 2017;33 http://www.scielo.br/j/csp/a/hNvqg5hQ79GR M5zhRQSnNhS/?lang=en

38 Reuters. Indonesia to slow down pace of tobacco tax hike due to pandemic, Government \& Economy. The Business Times [Internet], 2020. Available: https:// www.businesstimes.com.sg/government-economy/indonesia-to-slow-down-pace-oftobacco-tax-hike-due-to-pandemic [Accessed 8 Apr 2021].

39 Lencucha R, Thow AM. Intersectoral policy on industries that produce unhealthy commodities: governing in a new era of the global economy? BMJ Glob Health 2020;5:e002246.

40 Arias D, Vieira PA, Contini E. Agriculture productivity growth in Brazil [Internet]. World Bank, 2017. Available: https://elibrary.worldbank.org/doi/abs/10.1596/32202 [Accessed 02 Apr 2021].

41 Appau A, Drope J, Labonté $\mathrm{R}$, et al. Disentangling regional trade agreements, trade flows and tobacco affordability in sub-Saharan Africa. Global Health 2017;13:81.

42 Santos-Paulino A, Thirlwall AP. The impact of trade Liberalisation on exports, imports and the balance of payments of developing countries. Econ $\mathrm{J}$ 2004;114:F50-72.

43 Monograph 21. The economics of tobacco and tobacco control. 50.

44 Labonté $\mathrm{R}$, Lencucha R, Drope J, et al. The institutional context of tobacco production in Zambia. Global Health 2018;14:5.

45 Omaswa F, Boufford Jl. African Centre for Global Health and Social Transformation, New York Academy of Medicine. Strong ministries for strong health systems: handbook for ministers of health [Internet. Kampala, Uganda; New York: African Centre for Global Health and Social Transformation; New York Academy of Medicine, 2014. http://www.nyam.org/news/docs/pdf/SM-Handbook-070114.pdf

46 Fooks GJ, Gilmore AB, Smith KE, et al. Corporate social responsibility and access to policy élites: an analysis of tobacco industry documents. PLoS Med 2011;8:e1001076.

47 Rahman MS, Ahmed NAMF, Ali M, et al. Determinants of tobacco cultivation in Bangladesh. Tob Control 2020;29:692-4.

48 Kumar A, Singh H, Kumar S. Value chains of agricultural commodities and their role in food security and poverty alleviation - a synthesis. Agric Econ Res Rev 2011;24:169-81.

49 Neilson J. Value chains, neoliberalism and development practice: the Indonesian experience. Rev Int Polit Econ 2014;21:38-69.

50 Dercon S, Gilligan DO, Hoddinott J, et al. The impact of agricultural extension and roads on poverty and consumption growth in fifteen Ethiopian villages. Am J Agric Econ 2009;91:1007-21.

51 Burney JA, Naylor RL. Smallholder irrigation as a poverty alleviation tool in subSaharan Africa. World Dev 2012:40:110-23. 